\title{
TANTANGAN DAN KENDALA PELAKSANAAN KEBIJAKAN PENGALIHAN BEA PEROLEHAN HAK ATAS TANAH DAN BANGUNAN (BPHTB) DI PEMERINTAH KOTA GUNUNGSITOLI
}

\author{
CHALLENGES AND IMPEDIMENTS TOWARDSPOLICY \\ IMPLEMENTATION ON LAND AND BUILDING ACQUISITION TAX \\ TRANSFER AT GUNUNGSITOLI LOCAL GOVERNMENT
}

\author{
Septiana Dwiputrianti dan Yafet K. Buulolo
}

Sekolah Tinggi Ilmu Administrasi Lembaga Administrasi Negara(STIA LAN) Bandung Jl. Cimandiri 34-38 Bandung 40115

Email: tiana.dwi@gmail.com dan yafetbuulolo@gmail.com

Naskah diterima: 28 Maret 2015, revisi: 10 Februari 2016.

\begin{abstract}
The studi aims to review the impact of policy implementation on LandandBuildingAcquisition Tax Transfer (BPHTB) at Gunungsitoli Municipality, based on City Government RegulationNumber 2Year 2011. This study found that there are eight impediments faced by the local government of Gunungsitoli Municipality to implement the new policy of BPHTB, they are: (1) office building that is not feasible to be occupied and functioned as a work place as well as very limited space to serve taxpayers; (2) the local government has not had a proper long-term strategy to explore and enhance the revenue from the tax; (3) the organizational structure and working procedures of the department which are not adjusted with Regulation of Minister of Home Affairs Number 56 Year2010, (4) lack of workload analysis and job analysis, (5) lack of community understanding on BPHTB and payment procedure through the self-assessment system; (6) lack of implementation of the development for employees as well as limited fund for employees training; (7) preparation and formulation of tax regional regulations that are not based on academic study or not involving taxation experts; (8) disagreement between revenue agency and land agency in Nias Regency in conducting the payment receipt verification of BPHTB.
\end{abstract}

Keywords: local taxes, policy implementation, Gunungsitoli Municipality. 


\begin{abstract}
Abstrak
Artikel ini bertujuan untuk menganalisis dampak dari pelaksanaan Peraturan Walikota Gunungsitoli Nomor 2 Tahun 2011 berkaitan dengan pengalihan Bea Perolehan Hakatas Tanah dan Bangunan (BPHTB). Dalam pelaksanaan pengalihan BPHTB di Kota Gunungsitoli mengalami banyak kendala yang meliputi:(1) gedung kantor yang belum layak untuk ditempati dan difungsikan sebagai tempat bekerja, serta sangat terbatas untuk melakukan pelayanan kepada para wajib pajak; (2) pemerintah belum memiliki strategi jangka panjang yang tepat untuk menggali dan meningkatkan pendapatan dari hasil pemungutan pajak; (3) struktur organisasi dan tata kerja dinas yang masih belum disesuaikan dengan Permendagri Nomor 56 Tahun 2010, (4) tidak tersedianya analisis beban kerja dan analisis jabatan, (5) kurangnya pemahaman masyarakat tentang BPHTB dan prosedur pemungutan BPHTB melalui self assessment system; (6) kurangnya pelaksanaan pengembangan pendidikan bagi para pegawai serta keterbatasan anggaran untuk pelaksanaan pelatihan; (7) penyusunan dan perumusan peraturan-peraturan daerah terkait dengan pengelolaan pajak tidak melalui sebuah kajian akademis dari para pakar yang ahli dalam bidang perpajakan;(8) ketidaksepahaman dinas pendapatan dan kantorpertanahan Kabupaten Nias dalam pelaksanaan verifikasi tanda bukti pembayaran BPHTB oleh wajib pajak.
\end{abstract}

Kata kunci: pajak daerah, implementasi kebijakan, Pemerintah Kota Gunungsitoli.

\title{
A. PENDAHULUAN
}

Pokok perubahan mendasar dari UU Nomor 34 Tahun 2000 menjadi UU Nomor 28 Tahun 2009 tentang pajak daerah adalah pengalihan dua jenis pajak pusat menjadi pajak daerah. Kedua pajak tersebut adalah Bea Perolehan Hak atas Tanah dan Bangunan (BPHTB) dan Pajak Bumi dan Bangunan sektor Perdesaan dan Perkotaan (PBBP2). Pengalihan BPHTB menjadi pajak daerah diharapkan akan berdampak pada peningkatan penerimaan daerah sehingga akan mendorong derajat kemandirian keuangan pemerintah daerah serta mengurangi tingkat ketergantungan pemerintah daerah kepada pemerintah pusat. Dengan adanya pengalihan BPHTB menjadi pajak daerah menyebabkan terjadinya pemindahan pos penerimaan BPHTB yang sebelumnya berada pada pos dana bagi hasil pajak, berpindah ke pos pendapatan asli daerah. Dengan demikian desentralisasi BPHTB sangatlah berpengaruh terhadap besarnya pendapatan asli daerah khususnya penerimaan yang berasal dari pemungutan pajak.

Salah satu tindak lanjut dari pengalihan BPHTB menjadi pajak daerah di Pemerintah Kota Gunungsitoli adalah penetapan Peraturan Daerah Kota Gunungsitoli Nomor 2 Tahun 2011 tentang Pajak Daerah. Penetapan perda tersebut mengalami keterlambatan karena seyogianya batas waktu yang diberikan kepada daerah untuk membentuk perda tentang BPHTB adalah paling lambat 31 Desember 2010. Keterlambatan tersebut menimbulkan terjadinya loss income atau kehilangan penerimaan daerah dari BPHTB selama satu tahun karena pemungutan BPHTB baru dapat dilaksanakan oleh daerah setelah adanya perda yang mengatur. Pemungutan BPHTB di Kota Gunungsitoli telah berjalan selama dua tahun (2012 dan 2013). Gambar 1 menggambarkan target dan realisasi penerimaan BPHTB di Kota Gunungsitoli untuk tahun 2012 dan 2013: 


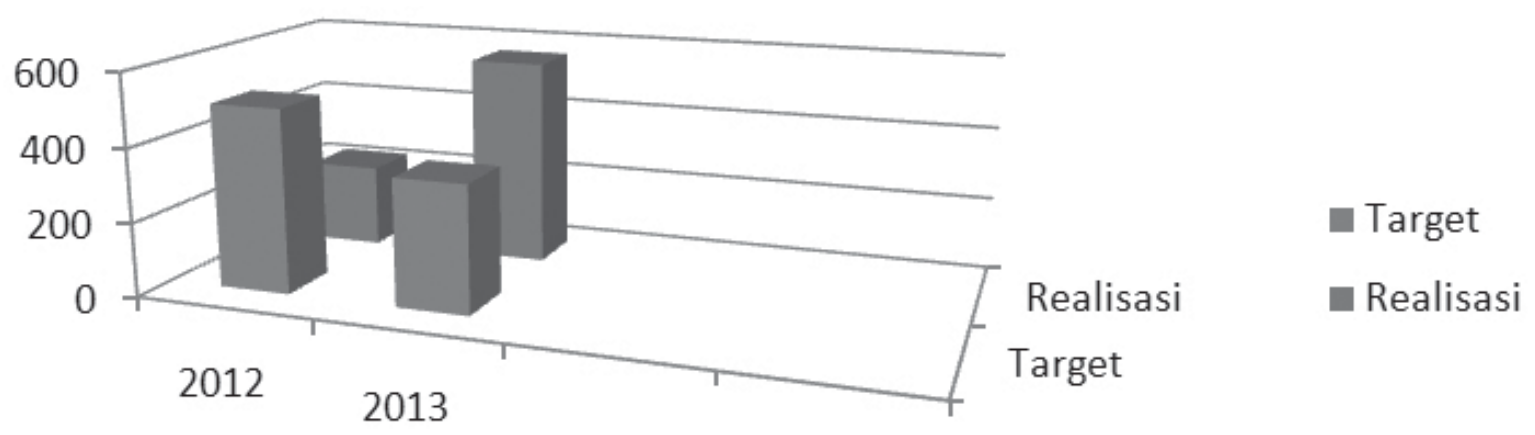

Gambar 1.

Target dan Realisasi Penerimaan BPHTB Kota Gunungsitoli

Sumber: Dinas PPKAD Kota Gunungsitoli (2015).

Dari realisasi penerimaan tersebut selama dua tahun terlihat bahwa realisasi penerimaan BPHTB pada tahun 2012 sebesar Rp. 226.481.000,- jauh dibawah target yang telah ditetapkan sebesar Rp. 500.000.000,-, tentunya hal ini disebabkan oleh beberapa kendala yang perlu segera diketahui oleh Pemerintah Kota Gunungsitoli dalam rangka meningkatkan realisasi penerimaan BPHTB untuk tahun-tahun berikutnya. Sedangkan untuk tahun 2013 realisasi penerimaan BPHTB di Kota Gunungsitoli mengalami kenaikan yaitu dari target sebesar Rp. 345.077.225,-- terealisasi sebesar Rp. 563.899.625,-, namun kenaikan tersebut bukanlah suatu indikator keberhasilan pemerintah Kota Gunungsitoli dalam pemungutan BPHTB karena dari target penerimaan BPHTB yang telah ditetapkan oleh Pemerintah Kota Gunungsitoli dari tahun 2012 ke tahun 2013 mengalami penurunan.

Hal yang perlu menjadi perhatiandalam pengalihan BPHTB menjadi pajak daerah adalah kesiapan dari pemerintah daerah dalam melaksanakan proses pengalihan tersebut. Kota Gunungsitoli merupakan daerah otonom yang baru terbentuk di Provinsi Sumatera Utara pada tahun 2008 sesuai dengan Undang-undang Nomor 47 Tahun 2008 dan baru efektif menjalankan roda pemerintahan pada akhir tahun 2009. Beberapa permasalahan yang timbul karena kekurangsiapan Pemerintah Kota Gunungsitoli dalam melaksanakan pengalihan BPHTB diantaranya adalah sebagai berikut:

1. Proses pemungutan BPHTB sering kali mengalami keterlambatan dan para pegawai pengelola BPHTB mengeluhkan ketidaknyamanan dalam melaksanakan tugas.

2. Tumpang tindih fungsi dan tugas dalam struktur organisasi Dinas Pendapatan Pengelolaan Keuangan dan Aset Daerah Kota Gunungsitoli sebagai pelaksana pengelolaan BPHTB

3. Masyarakat mengeluhkan pelayanan yang kurang memuaskan dari pegawai pengelola BPHTB dan masih terdapat masyarakat yang belum mengerti dan paham tentang BPHTB.

4. Sistem dan prosedur pelayanan BPHTB belum sesuai dengan system pemungutan pajak yang berlaku di Indonesia serta tarif pajak yang cukup tinggi sehingga sering terjadi rekayasa nilai transaksi dalam pelepasan hak atas tanah dan bangunan.

5. Ketidakharmonisan hubungan PPAT dan BPN di Kota Gunungsitoli dengan pemerintah daerah yang dilatarbelakangi oleh kurangnya perhatian Pemda atas peran pihak-pihak terkait dalam mendukung dan mensukseskan pelaksanaan pemungutan BPHTB.

Sehubungan dengan permasalahan di atas, perlu dilakukan suatu kajian mengenai kendala yang dihadapi oleh Pemerintah Kota Gunungsitoli dalam melaksanakan pengalihan Bea Perolehan Hak atas Tanah dan Bangunan (BPHTB) menjadi pajak daerah. Selain itu, perlu adanya suatu kajian di pemerintah Kota Gunungsitoli untuk rekomendasi dalam mengatasi kendala yang ada sehingga dapat terselesaikan. 


\section{B. TINJAUAN PUSTAKA}

Menurut Soemitro (Abuyamin, 2015:15),pajak adalah iuran rakyat kepada kas negara berdasarkan undang-undang (yang dapat dipaksakan) dengan tidak mendapat jasa timbal balik (kontra prestasi), yang langsung dapat ditunjukkan dan yang digunakan untuk membayar pengeluaran umum. Bea Perolehan Hak atas Tanah dan Bangunan atau selanjutnya disebut BPHTB adalah pajak yang dikenakan atas perolehan hak atas tanah dan atau bangunan. Selanjutnya, perolehan hak atas tanah dan atau bangunan adalah perbuatan atau peristiwa hukum yang mengakibatkan diperolehnya hak atas tanah dan atau bangunan oleh orang pribadi atau badan. Sedangkan hak atas tanah dan atau bangunan adalah hak atas tanah termasuk hak pengelolaan, beserta bangunan diatasnya, sebagaimana dimaksud dalam Undang-Undang Nomor 5 tahun 1960 tentang Peraturan Dasar Pokok Pokok Agraria, Undang-Undang Nomor 16 tahun 1985 tentang Rumah Susun, dan ketentuan perundang-undangan lainnya. Dasar hukum BPHTB adalah UU No. 28 tahun 2009 tentang Pajak Daerah Dan Retribusi Daerah.

Wajib pajak dari BPHTB adalah orang pribadi atau badan yang memperoleh hak atas tanah dan bangunan, sesuai dengan Pasal 86 Undang-undang Nomor 28 Tahun 2009 (Abuyamin, 2015:510). Menurut Undang-Undang Nomor 28 Tahun 2009 tarif Bea Perolehan Hak atas Tanah dan Bangunan (BPHTB) ditetapkan paling tinggi sebesar $5 \%$. Tarif Bea Perolehan Hak atas Tanah dan Bangunan (BPHTB) ditetapkan dengan peraturan daerah (Pasal 88 UU No. 28 Tahun 2009). Menurut Dwiputrianti (2012), penetapan tarif pajak adalah salah satu jenis barang publik, serta sebagai bagian yang tidak terpisahkan dari konsep akuntabilitas dan pelayanan publik yang semakin dituntut oleh masyarakat kepada pemerintah.

Adapuntujuan kebijakan pengalihan BPHTB sebagai pajak daerah menurut Undang-Undang Nomor 28 Tahun 2009 adalah sebagai berikut:

a. Memperluas objek pajak daerah dan retribusi daerah;

b. Menambah jenis pajak daerah dan retribusi daerah (termasuk pengalihan BPHTB menjadi Pajak Daerah);

c. Memberikan diskresi penetapan tarif pajak kepada daerah;

d. Menyerahkan fungsi pajak sebagai instrumen penganggaran dan pengaturan pada daerah.

Peraturan Bersama Menteri Keuangan dan Menteri Dalam Negeri No 186/PMK.07/2010 No 53/2010 menjelaskan dan mengatur tentang tugas dan tanggung jawab Pemerintah Daerah dalam pelaksanaan pengalihan BPHTB, tugas dan tanggungjawab tersebut adalah melaksanakan dan mempersiapakan sarana dan prasarana, Struktur organisasi dan tata kerja, Sumber daya manusia, Peraturan daerah, peraturan kepala daerah, dan SOP, serta kerjasama dengan pihak terkait, antara lain, kantor pelayanan pajak, perbankan, kantor pertanahan, dan notaris/PPAT.

\section{Sarana dan Prasarana}

Berdasarkan kemanfaatannya, Moenir (2000:120) membagi sarana dan prasarana dalam beberapa kategori:

1. Peralatan kerja, yaitu semua jenis benda yang berfungsi langsung sebagai alat produksi untuk menghasilkan barang atau berfungsi memproses suatu barang yang berlainan fungsi dan gunanya.

2. Perlengkapan kerja, yaitu semua jenis benda yang berfungsi sebagai alat pembantu tidak langsung dalam produksi, mempercepat proses, membangkit dan menambah kenyamanan dalam pekerjaan. 
3. Perlengkapan bantu atau fasilitas, yaitu semua jenis benda yang berfungsi membantu kelancaran gerak dalam pekerjaan, misalnya mesin ketik, mesin pendingin ruangan, mesin absensi, dan mesin pembangkit tenaga.

Hal ini dapat diindikasikan, bahwa sedikitnya terdapat beberapa jenis sarana dan prasarana yang harus disediakan oleh Pemerintah Kota Gunungsitoli dalam melaksanakan pengalihan BPHTB, seperti: ruang pelayanan, tempat Pelayanan untuk melayani wajib pajak BPHTB dan para Notaris/ PPAT, penyediaan ruang server, ruang pengolahan data dan informasi, serta pengadaan blanko atau formulir terkait dengan BPHTB serta surat-surat pelayanan (surat pengajuan keberatan, surat pengajuan keringanan, surat pengajuan pembatalan, surat penerbitan SPPT) dan lain sebagainya.

\section{Struktur Organisasi dan Tata Kerja (SOTK)}

Struktur organisasi adalah susunan komponen-komponen (unit-unit kerja) dalam organisasi. Menurut Robbins (1994:6), "Struktur organisasi menetapkan bagaimana tugas akan dibagi, siapa melapor kepada siapa, dan mekanisme koordinasi yang formal serta pola interaksi yang akan diikuti”.Lebih lanjut Sutarto (2012:43) menyatakan bahwa “Untuk membentuk struktur organisasi yang sehat dan efisien harus berpedoman kepada prinsip-prinsip organisasi, dimana prinsip-prinsip organisasi tersebut terdiri atas perumusan tujuan yang jelas, departemenisasi, pembagian kerja, koordinasi, pelimpahan wewenang, rentang kontrol, jenjang organisasi, kesatuan perintah, fleksibilias, keberlangsungan, kesinambungan”. Dari pernyataan tersebut, maka struktur organisasi yang efektif adalah yang memenuhi prinsip-prinsip organisasi yang meliputi adanya tujuan satuan organisasi yang jelas, kesesuaian pembagian kerja atau spesialisasi, adanya departementalisasi yang tepat, penerapan rentang kendali yang tepat, dan pengkoordinasian tugas-tugas sesuai dengan prosedur standar operasi. Berikut dijelaskan konsep dan teori dari beberapa hal tersebut.

\section{Tujuan Yang Jelas}

Sutarto (2012:63) mengemukakan bahwa:’Tiap-tiap satuan organisasi dan subsatuan organisasi harus dilahirkan dari suatu tujuan yang jelas selaras dengan tujuan organisasi”.Tahap-tahap tujuan adalah urut-urutan keseluruhan kebutuhan yang diusahakan untuk dicapai oleh suatu organisasi sehingga diketahui dengan jelas manakah tujuan pokok yang harus dicapai lebih dahulu dan manakah tujuan tambahan yang dapat dicapai pada tahap berikutnya. Tujuan pokok adalah kebutuhan yang menjadi dasar dibentuknya suatu organisasi, sedang tujuan tambahan adalah kebutuhan yang hendak dicapai oleh suatu organisasi karena sebagian tujuan pokok telah dapat dicapai dengan baik dan organisasi yang bersangkutan masih mempunyai kelebihan kemampuan.

\section{Depertementalisasi}

Menurut Murwani (2002:25), departementalisasi adalah “Aktivitas untuk menyusun satuansatuan organisasi yang akan diserahi bidang kerja tertentu atau fungsi tertentu. Fungsi adalah sekelompok aktivitas sejenis, berdasarkan kesamaan sifatnya atau pelaksanaannya. Dalam suatu organisasi terdapat dua satuan organisasi yaitu organisasi utama atau satuan-satuan organisasi yang berkedudukan dibawah pucuk pimpinan dan satuan organisasi lanjutan atau satuan-satuan organisasi yang berkedudukan dibawah satuan organisasi utama” 


\section{Pembagian Kerja/Spesialisasi}

Murwani (2002:29-30) juga mengemukakan bahwa dalam melakukan pembagian kerja hendaknya diperhatikan beberapa hal sebagai berikut:

a. Tiap-tiap satuan organisasi hendaknya memiliki rincian aktivitas yang jelas pada daftar rincian aktivitas;

b. Tiap-tiap pejabat dari pucuk pimpinan sampai dengan pejabat yang berkedudukan paling rendah harus memiliki rincian tugas yang jelas dalam suatu daftar rincian;

c. Jumlah tugas sebaiknya dibebankan kepada seorang pejabat, antara 4 sampai dengan 12 macam;

d. Variasi tugas bagi seorang pejabat hendaknya diusahakan yang sejenis atau erat hubungannya satu sama lain;

e. Beban aktivitas bagi seorang pejabat hendaknya diusahakan yang sejenis atau erat hubungannya satu sama lain;

f. Beban aktivitas bagi tiap-tiap satuan organisasi atau beban tugas masing-masing pejabat, hendaknya merata sehingga dapat dihindarkan adanya satuan organisasi yang terlalu banyak aktivitasnya dan ada satuan organisasi yang terlalu sedikit aktivitasnya, demikian pula dapat dihindarkan adanya pejabat yang terlalu bertumpuk-tumpuk tugasnya dan ada pejabat yang sangat sedikit tugasnya sehingga tampak terlalu banyak menganggur;

g. Penempatan para pejabat hendaknya tepat. Dasar yang digunakan antara lain kecakapan, keberanian, jenis kelamin, kekuatan, umur, kesehatan, kejujuran dan sebagainya;

h. Penambahan dan pengurangan pegawai hendaknya berdasarkan volume kerja;

i. Pembagian kerja yang menyangkut pejabat dalam suatu satuan organisasi jangan sampai menimbulkan pengkotakan jabatan;

j. Adanya penggolongan tugas (pekerjaan rutin, khusus, kreatif).

\section{Rentang Kendali}

Murwani (2002:33) mengemukakan bahwa rentang kontrol itu terbatas dan jumlah angka pedomannya adalah:

a. Untuk satuan utama jumlah pejabat bawahan langsung sebaiknya berkisar antara tiga sampai sepuluh orang;

b. Untuk satuan lanjutan jumlah pejabat bawahan langsung sebaiknya berkisar antara sepuluh sampai dengan duapuluh orang.

Namun demikian untuk membuat pertimbangan apakah jumlah jenjang itu benar atau tidak maka harus dipertanyakan, nilai apakah yang dapat disumbangkan oleh pekerjaan itu kepada organisasi dan apa yang terjadi apabila pekerjaan itu tidak ada.

\section{Mekanisme Koordinasi}

Koordinasi dalam organisasi sangat diperlukan. Pekerja pada tingkat bawah atau bawahan dalam melaksanakan tugasnya harus sejalan dengan tujuan organisasi secara keseluruhan, dan atasan langsung dalam organisasi perlu mengetahui pelaksanaan aktivitas dari orang-orang atau bawahannya dalam organisasi. Menurut beberapa ahli terdapat tiga metode untuk melakukan koordinasi, yaitu standardisasi proses kerja, standardisasi hasil, dan standardisasi keahlian. Dalam penelitian ini melakukan evalausi terhadap mekanisme koordinasi berdasarkan standardisasi proses kerja. Dimana dalam Tangkilisan (2005:201) menyebutkan bahwa standardisasi proses kerja adalah”Tugas-tugas dapat dikoordinasikan sesuai dengan prosedur standar operasi”. 
a. Sumber Daya Manusia (SDM)

Organisasi penting untung memperhatikan kualitas dari sumber daya manusianya. Menurut Irianto (Tangkilisan, 2005:191), “Ada dua elemen mendasar yang berkaitan dengan pengembangan sumber daya manusia, yaitu pendidikan dan keterampilan yang dimiliki oleh karyawan atau pekerja, karena kedua elemen ini berhubungan dengan perencanaan karir pekerja dan pada akhirnya bermuara pada kinerja organisasi yang berlangsung secara berkelanjutan”. Berbicara mengenai kedua aspek diatas, Notoatmodjo (Tangkilisan, 2005:191) mengemukakan bahwa: "Pendidikan merupakan faktor untuk menentukan penempatan formasi atau jabatan dalam suatu organisasi, sementara keterampilan (ability) berkaitan dengan kemampuan seseorang dalam menyelesaikan suatu pekerjaan secara efisien, tepat, dan efektif”.

\section{b. Peraturan Daerah (Perda)}

Pendekatan penyerahan sebagai urusan pemerintahan kepada penyelenggara pemerintahan di daerah. Negara mengakui keberadaan daerah sebagai organ negara yang menjalankan urusan pemerintahan di daerah. Penyerahan urusan tersebut sekaligus dengan penyerahan kewenangan pembentukan peraturan daerah kepada penyelenggara pemerintahan di daerah. Menurut Abuyamin (2015:21), “Asas-Prinsip pemungutan pajak adalah dasar-dasar umum pemungutan pajak yang dapat dijadikan pedoman, fundamen, patokan ataupun syarat dalam penyusunan undang-undang perpajakan dalam rangka pemungutan pajak”.

Dalam arti setiap pemerintah baik pusat maupun daerah dalam membuat peraturan dibidang perpajakan senantiasa selalu memperhatikan dan memper-timbangkan asas ataupun prinsip dalam pemungutan pajak. Selain itu juga harus mempertimbangkan keadaan atau kondisi potensi pajak yang ada diwilayah atau daerah masing-masing dengan beragam karakteristik yang ada.

\section{c. Kerjasama Dengan Pihak Terkait}

Menurut Tangkilisan (2005:160) “Lingkungan ekstern maupun intern, yaitu semua kekuatan yang timbul diluar batas-batas organisasi dapat mempengaruhi keputusan serta tindakan di dalam organisasi. Karenanya perlu diadakan kerjasama dengan kekuatan yang diperkirakan mungkin akan timbul. Kerjasama tersebut dapat didasarkan atas hak, kewajiban dan tanggungjawab masing-masing orang untuk mencapai tujuan”. Dari pernyataan tersebut, jelas bahwa keberhasilan organisasi sangat ditentukan oleh kemampuannya dalam menanggapi lingkungan secara tepat, dan salah satu caranya adalah melalui kerjasama antar unit dalam organisasi tersebut maupun dengan beberapa organisasi lain yang dianggap mampu membantu dalam mengantisipasi dan beradaptasi dengan perubahan lingkungan yang timbul.

Bardach (2012) menekankan pentingnya melihat fenomena suatu kebijakan berbasis kepada bukti (evidence) data dan informasi yang menunjukkan fakta dan kebenaran, serta menggunakan metode penggalian dan pengumpulanyang tepat dalam membuat alternatif kebijakan yang tepat untuk menyelesaikan permasalahan yang ada. Hal ini juga didukung oleh Considine (2005: 219) menekankan pentingnya proses dalam membuat kebijakan yang dilandasi oleh moral, etika dan nilai akuntabilitas disamping kompetensi dari aspek substansi.

\section{METODE PENELITIAN}

Penelitian ini menggunakan metode penelitian deskriptif dengan pendekatan kualitatif yang bertujuan menggambarkan mengidentifikasi kendala dalam pelaksanaan pengalihan dan pengelolaan BPHTB di Pemerintah Kota Gunungsitoli setelah dialihkan menjadi pajak daerah. Data yang dibutuhkan difokuskan pada penjelasan dan pendapat informan tentang pelaksanaan pengalihan 
dan pengelolaan BPHTB setelah menjadi pajak daerah Kota Gunungsitoli, bersifat sebagai data primer. Sedangkan data sekunder berupa dokumen atau arsip yang berkaitan dengan pelaksanaan pengalihan BPHTB dari pajak pusat menjadi pajak daerah dan data lainnya yang masih ada kaitannya dengan tujuan penelitian ini.

Tabel 1.

Daftar Informan Penelitian

\begin{tabular}{|c|l|l|}
\hline No. & \multicolumn{1}{|c|}{ Substansi } & \multicolumn{1}{|c|}{ Informan } \\
\hline 1. & Sarana dan Prasarana & $\begin{array}{l}\text { a. Kepala Dinas PPKAD } \\
\text { b. Kepala Bidang Pendapatan }\end{array}$ \\
\hline 2. & SOTK & $\begin{array}{l}\text { a. Kepala Dinas PPKAD } \\
\text { b. Kepala Bagian Organisasi }\end{array}$ \\
\hline 3. & SDM & $\begin{array}{l}\text { a. Kepala Dinas PPKAD } \\
\text { b. Kepala BKD } \\
\text { c. Kepala Bidang Pendapatan }\end{array}$ \\
\hline 4. & Perda, Perkada dan SOP & $\begin{array}{l}\text { a. Kepala Dinas PPKAD } \\
\text { b. Kepala Bidang Pendapatan }\end{array}$ \\
\hline 5. & Kerjasama dengan pihak terkait & $\begin{array}{l}\text { a. Kepala Dinas PPKAD } \\
\text { b. Kepala Bidang Pendapatan } \\
\text { c. Notaris/PPAT } \\
\text { d. Kepala BPN Nias }\end{array}$ \\
\hline 6. & Pelayanan BPHTB & \begin{tabular}{l} 
Wajib Pajak BPHTB (5 Orang) \\
\hline
\end{tabular} \\
\hline
\end{tabular}

Teknik pengumpulan data dilakukan dengan wawancara, observasi, dan studi dokumentasi. Untuk verifikasi data penulis menggunakan trianggulasi sumber dan metode. Sedangkan untuk teknik analisis data digunakan model interaktif Miles \& Huberman Silalahi (2012:340) yang terdiri dari tahapan pengumpulan data, reduksi data, penyajian data, dan proses menarik kesimpulan. Selain itu dalam analisis data, penulis juga menggunakan teknik content analysis dan visual interpretasi.

\section{HASIL DAN PEMBAHASAN}

Tantangan dan kendala yang dihadapi Pemerintah Kota Gunungsitoli dalam pelaksanaan pengalihan BPHTB menjadi pajak daerahpada dasarnya disebabkan oleh kurangnya kesiapan pemerintah daerah dalam melaksanakan tugas dan tanggunjawab dalam melaksanakan pengalihan BPHTB menjadi pajak daerah sebagaimana tertuang dalam Peraturan Bersama Menteri Keuangan dan Menteri Dalam Negeri No 186/PMK.07/2010 - No 53/2010. Menurut peraturan tersebut terdapat lima dimensi yang menjadi tugas dan tanggungjawab pemerintah daerah dalam melaksanakan pengalihan BPHTB yaitu sarana dan prasarana, SOTK, peraturan daerah/SOP, SDM, dan kerjasama dengan beberapa pihak terkait. Kelima dimensi tersebut di atas saling berkaitan dan mendukung satu sama lain sehingga untuk mengidentifikasi kendala dan tantangan dalam pengalihan BPHTB menjadi pajak daerah di Pemerintah Kota Gunungsitolidiperlukan pengkajian dan analisis terhadap kondisi dan ketersediaan kelima dimensi tersebut berdasarkan data dan fakta yang ada dilapangan. Yang menjadi lokus dalam penelitian ini adalah Dinas Pendapatan Pengelolaan Keuangan dan Aset Daerah (DPPKAD) Kota Gunungsitoli sebagai dinas teknis yang bertugas dalam mengelola BPHTB di Kota Gunungsitoli.

\section{Kondisi Sarana dan PrasaranaDPPKAD Kota Gunungsitoli}

Menurut Moenir (2000:120) sarana dan prasarana terdiri dari peralatan kerjayang berfungsi 
sebagai alat produksi, perlengkapan kerja yang berfungsi sebagai alat pembantu, mempercepat proses, dan memberi kenyamanan dalam melakukan pekerjaan, dan yang terakhir adalah perlengkapan bantu atau fasilitas yang berfungsi dalam membantu kelancaran gerak dalam pekerjaan. Salah satu sarana dan prasarana yang kondisinya sangat memprihatinkan adalah gedung kantor dan ruangan DPPKAD sebagaiamana pada gambar berikut:

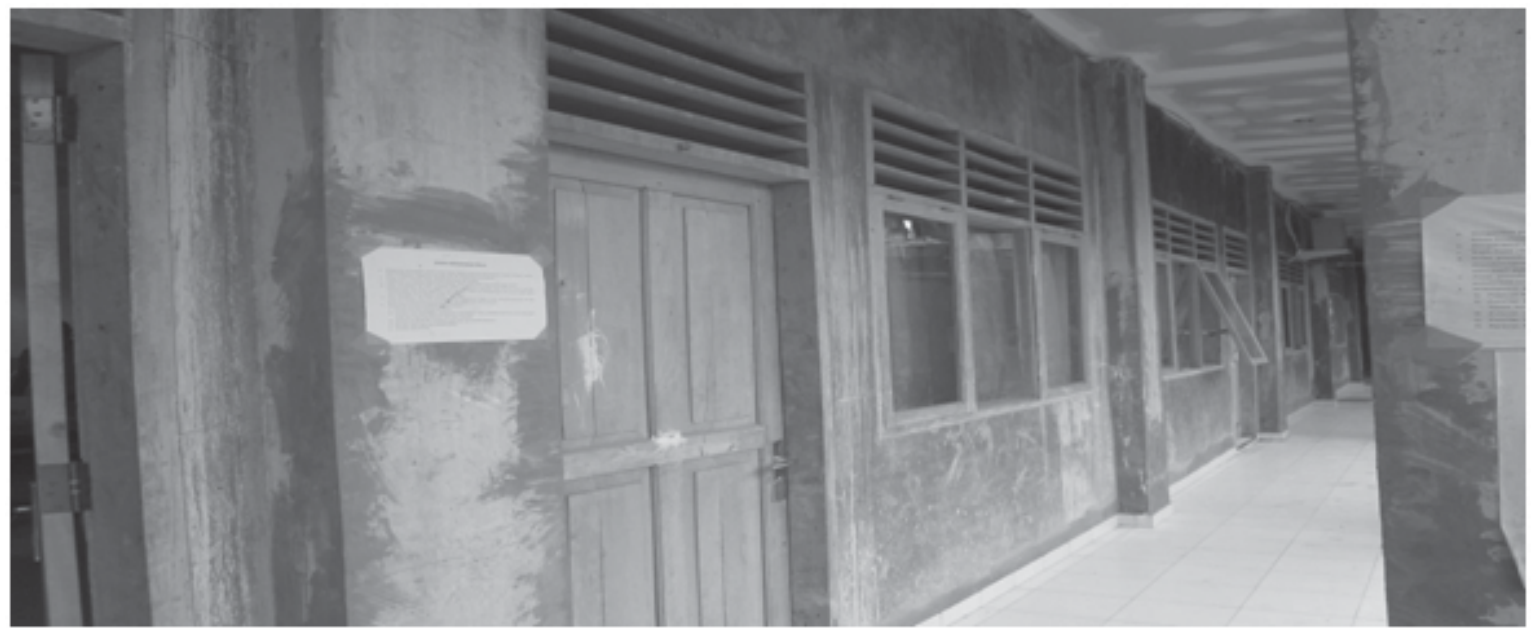

Sumber : Dokumentasi Penulis (2014)

Gambar 2.

Tampak Luar Gedung DPPKAD Kota Gunungsitoli

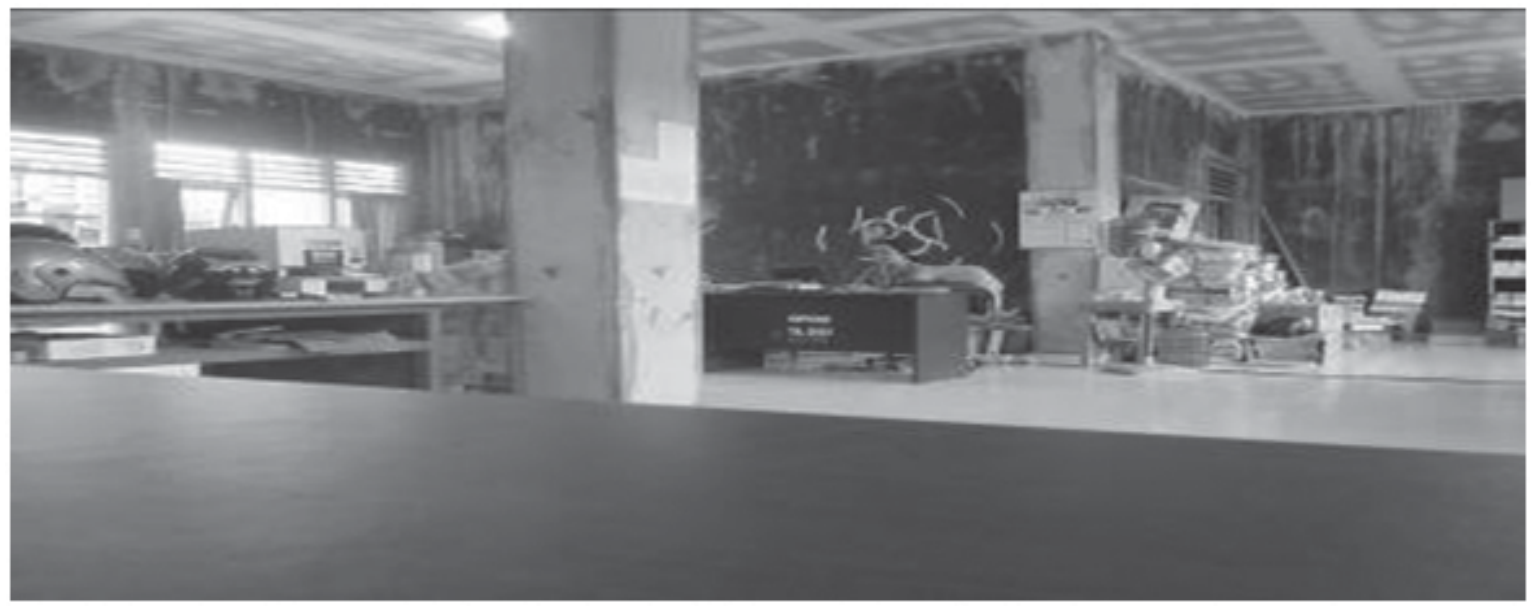

Sumber : Dokumentasi Penulis (2014)

Gambar3.

Ruangan Bagian Dalam Gedung Kantor DPPKAD Kota Gunungsitoli (Bid. Pendapatan)

Gedung kantor DPPKAD merupakan bangunan baru yang belum selesai pembangunannya namun telah ditempati dan digunakan oleh DPPKAD karena keterbatasan ketersediaan gedunggedung kantor di pemerintah Kota Gunungsitoli.Kondisi gedung tersebut sangat mengganggu aktifitas perkantoran baik dari segi kenyamanaan pegawai dalam bekerja maupun kenyamanan masyarakat dalam berurusan dikantor DPPKAD Kota Gunungsitoli.

Kondisi tersebut diperparah lagi dengan ketersediaan ruangan kerja dan ruangan pelayanan yang jumlahnya sangat terbatas pada bidang Pendapatan DPPKAD. Ruangan yang tersedia hanya 
terdiri dari dua ruangan yang digunakan untuk satu ruangan kepala bidang dan satu lagi difungsikan untuk ruangan kepala seksi dan staf, sekaligus untuk ruangan pelayanan dan server. Kondisi tersebutmenyebabkan keterbatasan gerakpegawai dalam melakukan proses kerja dan menghambat kelancaran pelayanan kepada masyarakat.

\section{Struktur Organisasi dan Tata Kerja (SOTK) dan Penerapan Prinsip-Prinsip Organisasi pada DPPKAD Kota Gunungsitoli}

SOTK DPPKAD berdasarkan Peraturan Walikota Gunungsitoli Nomor 3 Tahun 2009 masih berpedoman pada Permendagri Nomor 57 Tahun 2007. Pengalihan BPHTB menjadi pajak daerah merupakan kebijakan dari pemerintah pusat dengan diterbitkanya Undang-Undang Nomor 28 tahun 2009 tentang Pajak Daerah dan Retribusi Daerah yang mengharuskan adanya perubahan organisasi khususnya struktur dan fungsi pada pemerintahan daerah dalam hal ini satuan kerja yang mengelola pendapatan atau pajak daerah sesuai dengan Peraturan Menteri Dalam NegeriNomor 56 Tahun 2010 tentang Perubahan atas Peraturan Menteri Dalam Negeri Nomor 57 Tahun 2007 tentang Petunjuk Teknis Penataan Organisasi Perangkat Daerah. Permasalahannya, Pemerintah Kota Gunungsitolimasih belum menyesuaikan SOTK Dinas PPKAD dengan Peraturan yang baru masih berpedoman pada peraturan yang lama.

Selain itu menurut Sutarto (2012:43) menyatkan bahwa "Untuk membentuk struktur organisasi yang sehat dan efisien harus berpedoman kepada prinsip-prinsip organisasi, dimana prinsip-prinsip organisasi tersebut terdiri Perumusan tujuan yang jelas, Departemenisasi, Pembagian kerja, Koordinasi, Pelimpahan wewenang, Rentang kontrol, Jenjang organisasi, Kesatuan perintah, Fleksibilias, Keberlangsungan, kesinambungan”.

\section{Tujuan}

Tujuan Dinas PPKAD Kota Gunungsitoli dituangkan dalam Rencana Kerja DPPKAD Tahun 2011/2016 dimana salah satu dari tujuan tersebut adalah meningkatkan pendapatan asli daerah yang diantaranya berasal dari pajak daerah yaitu BPHTB, guna mendukung pelaksanaan roda pemerintahan dalam melaksanakan pembangunan dan pelayanan kepada masyarakat. Kendala utama yang dihadapi oleh DPPKAD dalam mewujudkan tujuan tersebut adalah tidak adanya strategi yang tepat dari DPPKAD untuk mengembangkan dan meningkatkan pendapatan dari pemungutan BPHTB di Pemerintah Kota Gunungsitoli. Berdasarkan data lapangan, kebutuhan akan lahan bersertifikat di Kota Gunungsitoli dari waktu ke waktu mengalami peningkatan yang signifikan, pada tahun 2009 luas lahan bersertifikat yang terdiri dari HGB sebanyak 16.129 dan HM sebanyak 546.641. Untuk tahun 2010, HGB meningkat menjadi 104.000 dan HM menjadi 695.238. Peningkatan lahan bersertifikat tersebut menunjukan potensi BPHTB yang sangat besar di daerah Kota Gunungsitoli. Namun dalam pelaksanaannya potensi tersebut tidak semuanya dapat diidentifikasi oleh Pemerintah Kota Gunungsitoli sehingga mengakibatkan hilangnya sebagian besar pendapatan dari sector BPHTB. Dari hasil wawancara dan pengamatan penulis dilapangan terdapat dua hal penyebab kendala dalam identifikasi potensi BPHTB di Pemerintah kota Gunungsitoli, pertama adalah tingginya tarif pajak BPTHB yang diberlakukan oleh DPPKAD sebesar lima persen (5\%) sehingga sering sekali terjadi rekayasa dan penghindaran pajak oleh wakib pajak BPHTB. Kedua adalah data yang kurang valid, masih banyak terdapat lahan tanah dan bangunan milik masyarakat yang belum terdata dalam database DPPKAD hal ini disebabkan oleh lamanya proses pengalihan data dari pusat kedaerah dan juga berkaitan dengan kurangnya koordinasi pemerintah Kota Gunungsitoli dengan Badan Pertanahan Nasional dan PPAT dalam melakukan pendataan lahan dan bangunan di wilayah Kota Gunungsitoli. 


\section{Departementalisasi}

Berikut penggalan Struktur Organisasi DPPKAD pada bidang pendapatan Kota Gunungsitoli:

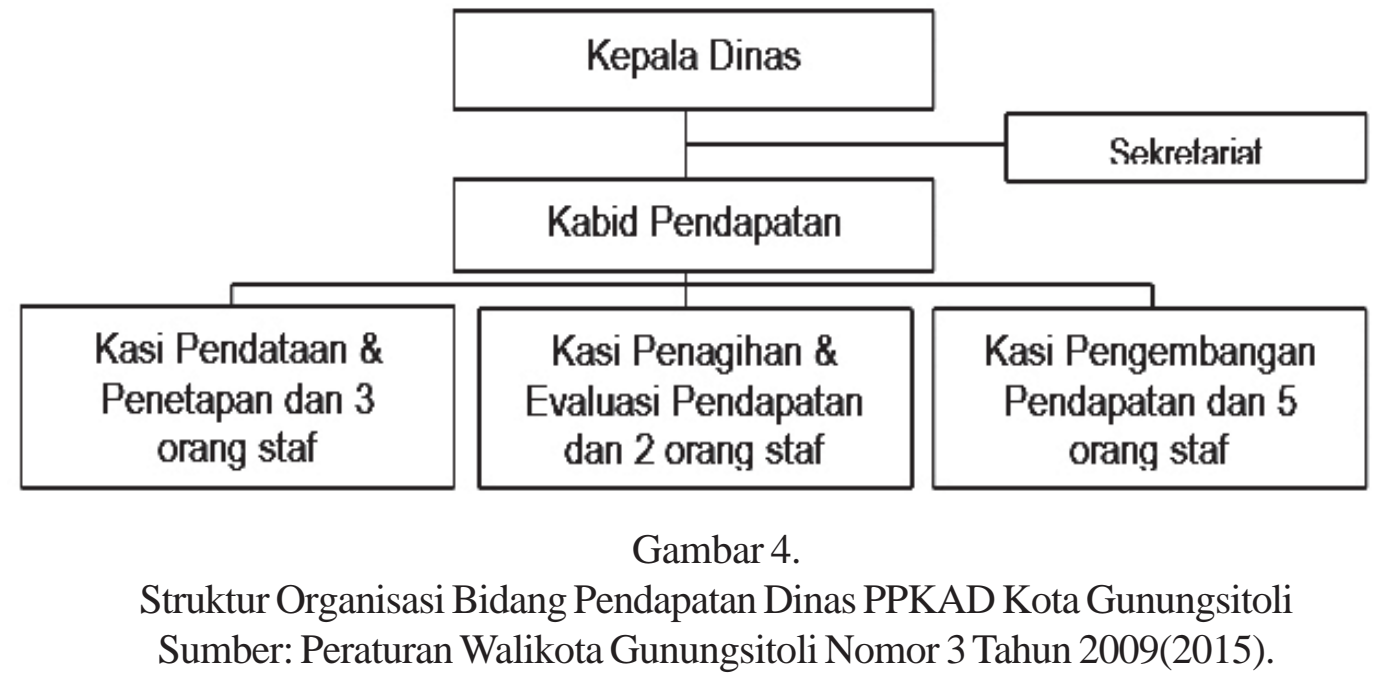

Menurut Wursanto (2005:242-247) terdapat enam macam departementalisasi yaitu departementalisasi fungsional, departemen-talisasi produk, departementalisasi wilayah, departementalisasi proses, departementalisasi pelanggan, dan departementalisasi campuran. Jenis departementalisasi pada bidang pendapatan DPPKAD adalah departemen-talisasi fungsional karena satuan-satuan kerja dikelompokan berdasarkan tugas dan fungsi yang sejenis seperti bidang pendapatan yang terdiri dari seksi pendataan, penagihan, dan pengembangan pendapatan. Salah satu kendala yang dihadapi dalam departementalisasi bidang pendapatan DPPKAD adalah SOTK DPPKAD masih berpedoman pada Permendagri No. 57 Tahun 2010 belum menyesuaikan dengan Permendagri No. 56 tahun 2010 dimana seharusnya pengelompokan kerja atau departementalisasi pada DPPKAD mengalami penambahan dan perubahan fungsi yaitu fungsi penyusunan kebijakan pelaksanaan pemungutan, pengolahan data dan informasi, pelayanan, penagihan, pengawasan dan penyelesaian sengketa pemungutan BPHTB, serta pelaporan dan pertanggungjawaban tugas. Kondisi tersebut menyebakan tumpang tindih pekerjaan dalam tubuh DPPKAD Kota Gunungsitoli khususnya dalam menangani masalah BPHTB.

\section{Pembagian Kerja/Spesialisasi}

Sutarto (Murwani, 2002:29-30) mengemukakan bahwa dalam melakukan pembagian kerja hendaknya diperhatikan beberapa hal antara lain rincian aktivitas yang jelas, jumlah tugas, variasi tugas, beban aktivitas yang sejenis dan merata, penempatan para pejabat yang tepat, penambahan dan pengurangan pegawai hendaknya berdasarkan volume kerja, menghindari pengkotakan jabatan, dan adanya penggolongan tugas. Terdapat dua kendala yang dihadapi oleh DPPKAD dalam pelaksanaan pembagian kerja, yang pertama adalah kurangnya personil pegawai pada DPPKAD yang menangani pengelolaan pendapatan daerah, dari data dilapangan jumlah pegawai pada DPPKAD khususnya bidang pendapatan yaitu berjumlah 15 orang yang terbagi dalam tiga seksi. Penambahan pegawai tidak dapat dilakukan karena belum adanya analisis beban kerja dan analisis jabatan pada unit kerja tersebut sehingga belum diketahui dengan jelas berapa jumlah kebutuhan pegawai dan jabatan pada satuan kerja tersebut. Kondisi tersebut menyebabkan ketidakseimbangan beban kerja dengan personil yang menangani dimana lebih besar volume kerja dari pada jumlah 
SDM yang melaksanakan tugas tersebut.Kedua, penempatan personil pada DPPKAD belum sesuai dengan latar belakang pendidikan dan kompetensi yang dibutuhkan sehingga mengakibatkan kurang mampunya pejabat tersebut dalam menjalankan dan mengenali tugas-tugas pada pengelolaan BPHTB.

\section{Rentang Kendali}

Menurut Sutarto (2012:172) yang dimaksud dengan asas atau prinsip rentang kontrol adalah jumlah terbanyak bawahan langsung yang dapat dipimpin dengan baik oleh seorang atasan tertentu. Kepala bidang Pendapatan DPPKAD dibantu oleh tiga kepala seksi, Seksi pendataan dan penetapan memiliki 3 orang staf, seksi penagihan dan evaluasi pendapatan memiliki 2 orang staf, dan seksi pengembangan pendapatan memiliki 5 orang staf. Apabila dikaitkan dengan konsep dan teori yang digunakan, maka rentang kendali pimpinan terhadap bawahanya dapat dikatakan sangat baik karena atasan hanya fokus mengawasi beberapa orang staf saja. Namun demikian untuk membuat pertimbangan apakah jumlah jenjang itu benar atau tidak maka harus dipertanyakan, nilai apakah yang dapat disumbangkan oleh pekerjaan itu kepada organisasi dan apa yang terjadi apabila pekerjaan itu tidak ada.

\section{Pengkoordinasian tugas-tugas}

Metode dalam melakukan koordinasi terdiri dari standardisasi proses kerja, standardisasi hasil, dan standardisasi keahlian. Metode koordinasi yang diterapkan pada DPPKAD Kota Gunungsitoli adalah standardisasi proses kerja, dimana menurut Tangkilisan (2005:201) standardisasi proses kerja adalah tugas-tugas dapat dikoordinasikan sesuai dengan prosedur standar operasi. Berdasarkan Peraturan Walikota Gunungsitoli Nomor 3 Tahun 2012 tentang Sistem Dan Prosedur Pemungutan BPHTB Kota Gunungsitoli terdapat enam macam prosedur yang ditetapkan dalam proses pengelolaan BPHTB yang terdiri dari dalam pengelolaan BPHTB di Kota Gunungsitoli koordinasi proses kerja dilakukan:

a. Prosedur pengurusan akta pemindahan hak atas tanah dan bangunan.

b. Prosedur pembayaran BPHTB.

c. Prosedur penelitian surat setoran pajak daerah atau SSPD BPHTB.

d. Prosedur pendaftaran akta pemindahan hak atas tanah dan bangunan.

e. Prosedur pelaporan BPHTB.

f. Prosedur penagihan.

g. Prosedur pengurangan.

Dari hasil wawancara dan pengamatan dilapangankendala dalam berkoordinasi disebabkan oleh kurangnya pemahaman wajib pajak BPHTB tentang prosedur yang berlaku, sebagai contoh dalam prosedur penghitungan dan pembayaran BPHTB ditegaskan bahwa yang melakukan perhitungan dan pembayaran BPHTB adalah wajib pajak itu sendiri namun dalam pelaksanaan dilakukan oleh pihak PPAT atau Notaris. Kondisi tersebut jelas tidak sesuai dengan system pemungutan pajak yang berlaku di Indonesia yaitu Self-assessment System.

Konsistensi pelaksanaan prosedur yang telah ditetapkan dalam pengelolaan BPHTB masih belum terlaksana dengan baik. Masih terdapat ketidaksesuaian antara waktu penyelesaian pelayanan BPHTB yang seyogianya paling lama sepuluh hari namun dalam pelaksanaannya lebih dari sepuluh hari. Hal ini disebabkan karena kurangnya pengawasan terhadap pelaksanaan tugas oleh petugas sehingga terjadi kelalaian dalam memberikan pelayanan terbaik kepada wajib pajak. 


\section{Sumber Daya Manusia}

Berikut ini adalah data pegawai yang bertugas pada Bidang pendapatan DPPKAD Kota Gunungsitoli:

Tabel 2.

Data Pegawai Pada DPPKAD Kota Gunungsitoli

\begin{tabular}{|c|c|c|c|c|}
\hline No. & Jabatan & Jumlah & Pendidikan/Jumlah & Pelatihan \\
\hline 1 & $\begin{array}{l}\text { Kepala } \\
\text { Dinas }\end{array}$ & $\begin{array}{l}1 \\
\text { Orang }\end{array}$ & $\begin{array}{l}\text { S-1 Manajemen } \\
\text { Ekonomi }\end{array}$ & $\begin{array}{l}\text { Perpajakan dan } \\
\text { Pengelolaan } \\
\text { keuangan daerah }\end{array}$ \\
\hline 2. & $\begin{array}{l}\text { Kabid } \\
\text { Pendapatan }\end{array}$ & $\begin{array}{l}1 \\
\text { Orang }\end{array}$ & S-1 Ekonomi & Perpajakan \\
\hline 3. & $\begin{array}{l}\text { Kasi } \\
\text { Pendataan dan } \\
\text { Penetapan }\end{array}$ & $\begin{array}{l}1 \\
\text { Orang }\end{array}$ & S-1 Ekonomi & Perpajakan \\
\hline 4. & $\begin{array}{l}\text { Kasi } \\
\text { Penagihan dan } \\
\text { Evaluasi } \\
\text { Pendapatan }\end{array}$ & $\begin{array}{l}1 \\
\text { Orang }\end{array}$ & S-1 Ekonomi & $\begin{array}{l}\text { Dikaltpim IV dan } \\
\text { Penyusuna Renstra }\end{array}$ \\
\hline 5. & $\begin{array}{l}\text { Kasi } \\
\text { Pengembangan } \\
\text { Pendapatan }\end{array}$ & $\begin{array}{l}1 \\
\text { Orang }\end{array}$ & S-1 Ekonomi & Perpajakan \\
\hline 6. & Staf & 9 orang & $\begin{array}{l}\text { S-1 Ekonomi/2, S-1 Hukum/1, } \\
\text { S-1 Komputer/1,D-3 } \\
\text { Perpajakan/1, D-3 Akuntansi/2, } \\
\text { SMA dan SMK/3 }\end{array}$ & $\begin{array}{l}\text { Perpajakan dan } \\
\text { Pelatihan } \\
\text { pengalihan PBB- } \\
\text { P2 dan BPHTB }\end{array}$ \\
\hline
\end{tabular}

Sumber : DUK DPPKAD Kota Gunungsitoli (2014), diolah.

Dari segi kualitas salah satu kendala SDM pada Dinas PPKAD Kota Gunungsitoli adalah kurangnya pengembangan pendidikan para pegawai. Pengembangan pendidikan tersebut bagi para pegawai sangatlah penting utamanya dalam mengaktualisasi dan mengimplementasi-kan segala ilmu yang didapatkan pada saat mengikuti pendidikan. Sehingga ilmu yang dimiliki oleh pegawai tidak hanya terbatas pada pendidikan terakhir namun terus mengalami perkembangan. Selain itu dalam pengembangan pendidikan para pegawaijuga harus diperhatikan kebutuhan DPPKAD akan bidang ilmu dan keahlian yang dibutuhkan sesuai dengan tugas dan fungsi yang ada, sehingga dengan demikian akan melahirkan sumber daya aparatur yang berkompeten dalam bidangnya.Gambar 5 menunjukkan persentase jenjang pendidikan dan latar belakang pendidikan para pegawai yang bertugas di Bidang Pendapatan Dinas PPKAD Kota Gunungsitoli. 


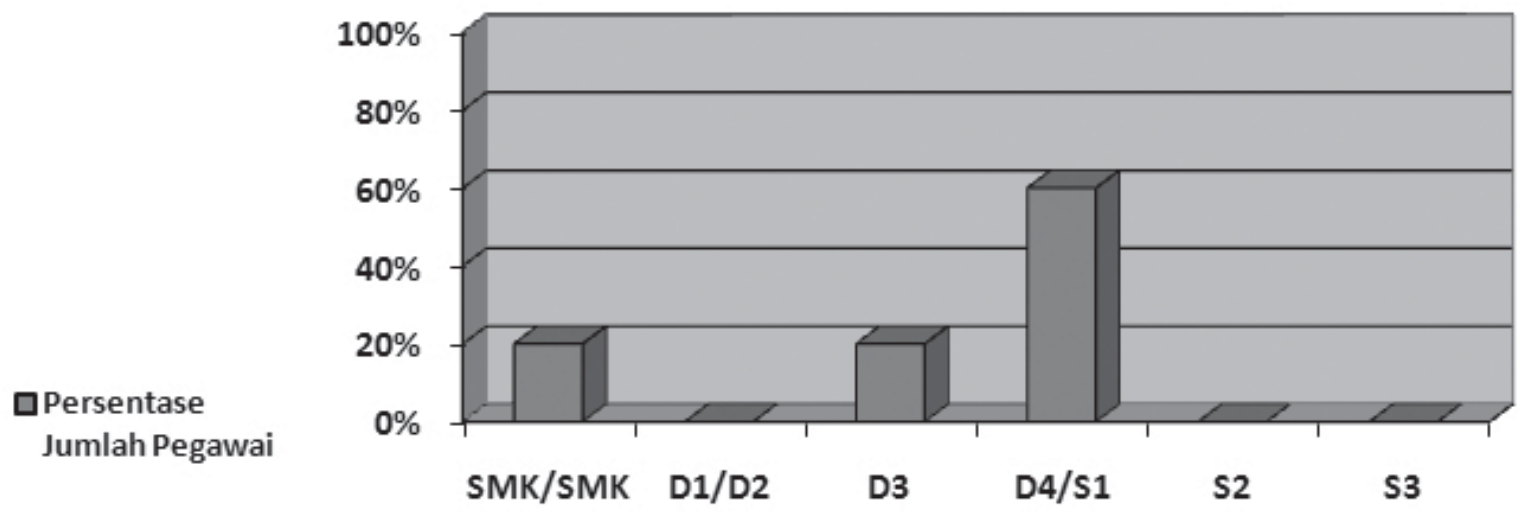

Sumber: DUK DPPKAD Kota Gunungsitoli (2014).

Keterangan : SMK/SMA:Akuntansi dan Pengadminsitrasian Umum (3 Orang)

D3 : 1 Perpajakan dan 2 Akuntansi (3 Orang)

S1 : 1 Hukum, 1 Komputer, 7 Ekonomi (9 Orang)

Gambar 5.

Persentase Jumlah Pegawai Bidang Pendapatan Dinas PPKAD

Kota Gunungsitoli BerdasarkanJenjang Pendidikan

Menurut Irianto (Tangkilisan, 2005:191) Ada dua elemen mendasar yang berkaitan dengan pengembangan sumber daya manusia, yaitu pendidikan dan ketrampilan yang dimiliki oleh karyawan atau pekerja, karena kedua elemen ini berhubungan dengan perencanaan karir pekerja dan pada akhirnya bermuara pada kinerja organisasi yang berlangsung secara berkelanjutan.Ketrampilan dapat diperoleh melalui pelatihan-pelatihan dalam bidang keahlian tertentu. Pelatihan sangatlah berguna dan bermanfaat dalam menciptakan pegawai yang produktif dibidang pengelolaan pendapatan. Kendala utama dalam pelatihan para pegawai di DPPKAD adalah keterbatasan anggaran untuk pelaksanaan pelatihan atau keikutsetaan pegawai pada pelatihan-pelatihan yang diadakan oleh pemerintah pusat maupun provinsi. Selain itu kendala lainya adalah keterbatasan pegawai pada DPPKAD yang mengakibatkan unit kerja tersebut jarang mengirimkan pegawainya untuk mengikuti pelatihan diluar daerahkarena terbebani dengan beban kerja yang begitu besar.

Dari segi kuantitas, jumlah pegawai pada DPPKAD Kota Gunungsitoli berjumlah 15 orang, berdasarkan wawancara dengan Kepala DPPKAD mengakui bahwa jumlah tersebut sangat terbatas dalam menangani tugas-tugas yang cukup banyak. Dari kondisi tersebut maka diperlukan adanya penambahan personil pada unit kerja tersebut, namun terkendala pada belum adanya analisis beban kerja dan analisis jabatan pada DPPKAD sehingga tidak diketahui jumlah pegawai dan jabatan yang dibutuhkan oleh DPPKAD Kota Gunungsitoli

\section{Kelengkapan dan Muatan Peraturan Daerah tentang BPHTB}

Berikut ini akan dirinci kelengkapan muatan peraturan daerah tentang pengelolaan BPHTB di Kota Gunungsitoli dibandingkan dengan amanat Undang-Undang Nomor 28 Tahun 2009, adalah sebagai berikut: 
Tabel 3.

Kelengkapan Muatan Perda Dan Perwali Tentang Pengelolaan BPHTB di Kota Gunungsitoli

\begin{tabular}{|l|l|l|l|}
\hline No & \multicolumn{1}{|c|}{ UU No. 28 Tahun 2009 } & \multicolumn{1}{|c|}{ Peraturan Daerah } & \multicolumn{1}{|c|}{ Keterangan } \\
\hline 1. & Nama, Objek dan Subjek & Perda No. 2/2011,Ps1 68,69,70 & Lengkap \\
\hline 2. & $\begin{array}{l}\text { Dasar Pengenaan, Tarif, dan Cara } \\
\text { Perhitungan }\end{array}$ & Perda No. 2/2011,Ps1 71,72,73 & Lengkap \\
\hline 3. & Wilayah Pemungutan & Perda No. 2/2011,Ps1 78 & Lengkap \\
\hline 4. & Masa Pajak & Perda No. 2/2011,Ps1 79 & Lengkap \\
\hline 5. & Penetapan & Perda No. 2/2011,Ps1 81 & Lengkap \\
\hline 6. & Pembayaran dan Penagihan & Perda No. 2/2011,Ps1 90, 91 & Lengkap \\
\hline 7. & Kadaluwarsa Pajak & Perda No. 2/2011,Ps197 & $\begin{array}{l}\text { Belum ada } \\
\text { Perwali }\end{array}$ \\
\hline 8. & Sanksi Administratif & Perda No. 2/2011,Ps1 99 & Lengkap \\
\hline 9. & Tanggal Mulai Berlaku & Perda No. 2/2011,Ps1 79 & Lengkap \\
\hline 10. & NPOPTKP & Perda No. 2/2011,Ps1 71 ayat5 & Lengkap \\
\hline 11. & Sistem Pelaporan Pembuatan Akta & Perda No. 2/2011,Ps1 75,76,77 & $\begin{array}{l}\text { Belum ada } \\
\text { Perwali }\end{array}$ \\
\hline 12. & Keringanan Pokok Pajak & Perda No. 2/2011,Ps1 96 & $\begin{array}{l}\text { Belum ada } \\
\text { Perwali }\end{array}$ \\
\hline 13. & $\begin{array}{l}\text { Tata cara penghapusan piutang pajak } \\
\text { yang kadaluwarsa }\end{array}$ & Perda No. 2/ 2011,Ps1 98 & $\begin{array}{l}\text { Belum ada } \\
\text { Perwali }\end{array}$ \\
\hline 15. & Asas Timbal Balik & Belum ada Perda & Menyesuaikan \\
\hline 15. & Tata Cara Pemeriksaan Pajak & Belum ada Perda & dibutuhkan \\
\hline 16. & Insentif Pemungut Pajak & Perda No. 2/2011,Ps1 100 & $\begin{array}{l}\text { Belum ada } \\
\text { Perwali }\end{array}$ \\
\hline
\end{tabular}

Sumber : Perda No. 2 Tahun 2011 dan Peraturan Walikota Gunungsitoli No. 3 Tahun 2013, diolah.

Persentase dari kelengkapan muatan peraturan-peraturan daerah tentang pengelolaan BPHTB di Kota Gunungsitoli dapat dilihat pada gambar di bawah ini:

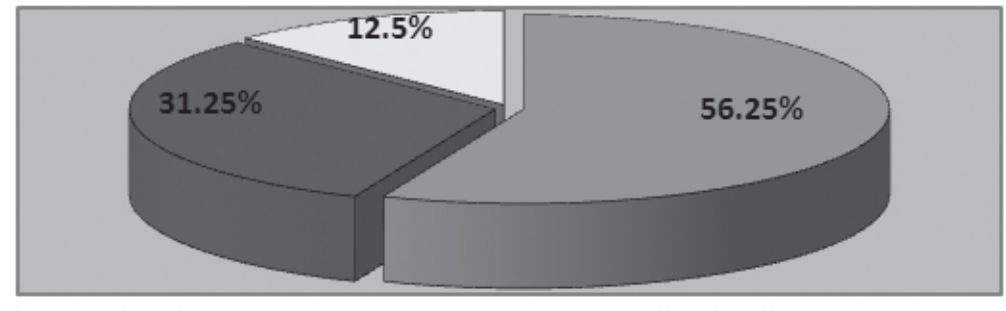

口Lengkap 口Belum Lengkap/Belum diatur lebih lanjut Melalui Perwal 口 Belum Ada/Belum diatur melalui Perda atau Perwal

Sumber : Data diolah(2014)

Gambar 6.

Persentase Kelengkapan Peraturan Daerah Kota Gunungsitoli Tentang Pengelolaan BPHTB

Dari gambar 6 di atas, dapat dijelaskan bahwa sebesar 31,25\% dari muatan peraturan daerah dan Peraturan Walikota Gunungsitoli tentang pemungutan BPHTB masih belum lengkap dan sebesar 12,5\% belum diatur sama sekali utamanya dalam beberapa substansi yang diamanatkan oleh Undangundang Nomor 28 Tahun 2009. Sedangkan menurut Abuyamin (2014:21) mengatakan bahwaAsasPrinsip pemungutan pajak adalah dasar-dasar umum pemungutan pajak yang dapat dijadikan pedoman, fundamen, patokan ataupun syarat dalam penyusunan undang-undang perpajakan dalam 
rangka pemungutan pajak. Dalam arti setiap pemerintah baik pusat maupun daerah dalam membuat peraturan dibidang perpajakan senantiasa selalu memperhatikan dan mempertimbangkan asas ataupun prinsip dalam pemungutan pajak. Selain itu juga harus mempertimbangkan keadaan atau kondisi potensi pajak yang ada diwilayah atau daerah masing-masing dengan beragam karakteristik yang ada.

Berdasarkan hasil wawancara dan pengamatan dilapangan, ketidaklengkapan peraturan daerah maupun peraturan lainnya tentang pengelolaan BPHTB di Kota Gunungsitoli disebabkan oleh belum dilaksanakannya kajian secara akademis terhadap muatan-muatan peraturan yang akan disusun dan ditetapkan. Padahal sesuai dengan prosedur pembuatan produk hukum daerah makapenyusunan dan penetapan sebuah peraturan daerah atau kepala daerah harus melalui sebuah kajian secara akademis dari para pakar ahli sesuai dengan muatan peraturan tersebut. Sebagai contoh belum adanya peraturan daerah atau peraturan walikota tentang tata cara pemeriksaan Pajak BPHTB di Kota Gunungsitoli, hal ini sebenarnya sangat perlu ditetapkan melalui peraturan daerah karena pemeriksaan pajak merupakan suatu substansi yang dapat berfungsi dalam pengawasan pelaksanaan pemungutan pajak, dapat mencegah terjadinya penggelapan dan penghindaran pajak sehingga kontrol dari pemerintah daerah terhadap pemungutan BPHTB dapat terlaksana dengan baik dan memiliki kekuatan hukum serta prosedur dalam pelaksanaan pemeriksaan pajak BPHTB, apabila hal tersebut dapat terlaksana maka secara tidak langsung akan berdampak pada peningkatan penerimaadaerah dari sektor pemungutan BPHTB.

Kendala lain yang berkaitan dengan peraturan daerah tentang BPHTB di Pemerintah Kota Gunungsitoli adalah belum adanya peraturan walikota yang mengatur tentang pemberian dan pemanfaatan insentif kepada pemungut pajak BPHTB. Insentif dapat berfungsi untuk meningkaatkan motifasi dan kesejahteraan petugas pemungut BPHTB dan pihak lainya seperti Notaris/PPAT. Pemberian insentif dapat diberikan berdasarkan pencapaian kinerja dari masing-masing pemungut pajak, dengan perlakuan tersebut maka pemungut pajak akan termotivasi untuk melakasanakan tugasnya lebih baik lagi dan bersaing sehat untuk berkontribusi dalam pemungutan dan menemukan potensi BPHTB yang selama ini masih belum terdata pada DPPKAD Kota Gunungsitoli.

\section{Hubungan Kerjasama dengan BPN Terkait Dengan Verifikasi SPPD BPHTB}

Menurut Tangkilisan (2005:160) “Lingkungan ekstern maupun intern, yaitu semua kekuatan yang timbul diluar batas-batas organisasi dapat mempengaruhi keputusan serta tindakan di dalam organisasi. Karenanya perlu diadakan kerjasama dengan kekuatan yang diperkirakan mungkin akan timbul. Dalam hal kerjasama dengan pihak terkait, terdapat tiga instansi yang menjadi prioritas Pemerintah Kota Gunungsitoli untuk menjalin kerjasama dalam pengelolaan BPHTB yaitu Kantor Pertanahan Kabupaten Nias, Notaris/PPAT, dan Kantor Pelayanan Pajak Pratama Sibolga. Untuk kerjasama dengan Kantor Pertanahan Kabupaten Nias, kebijakan yang perlu diprioritaskan adalah pelakanaan verifikasi SPPD BPHTB yang efektif agar tidak mengganggu pelayanan penerbitan hak atas tanah atau bangunan. Untuk Notaris/PPAT lebih diprioritaskan kerjasama dalam hal sosialisasi dan meningkatkan kesadaran wajib pajak untuk membayar BPHTB. Sedangkan untuk Kantor Pelayanan Pajak Pratama Sibolga lebih difokuskan pada pelatihan-pelatihan pegawai, konsultasi, dan pengolahan data BPHTB melalui sistem aplikasi jaringankomputer dan internet.

Salah satu kendala utama yang terjadi pada Pemerintah Kota Gunungsitoli terkait dengan kerjasama dengan pihak-pihak terkait adalah sering timbulnya ketidaksepahaman antar kedua belah pihak dalam mendukung kebijakan satu sama lain. Sebagai contoh adanya perbedaan persepsi antara BPN dan DPPKAD menanggapi Surat Edaran Kepala BPN RI Nomor 5/SE/IV/2013 menjelaskan tentang peniadaan verifikasi SSPD BPHTB atau pengecekan tanda bukti pembayaran 
BPHTB dalam persyaratan pengurusan akta tanah dan bangunan yang bertujuan untuk mempercepat proses penerbitan akta. DPPKAD beranggapan bahwa verifikasi SSPD BPHTB atau pengecekan tanda bukti pembayaran BPHTB harus tetap dilaksanakan dalam proses pemungutan BPHTB di Kota Gunungsitoli mengingat tujuan dari dilakukannya verfikasi tersebut adalah untuk mencegah penggelapan dan penghindaran pajak oleh wajib pajak BPHTB dan salah satu upaya dalam meningkatkan PAD dari sektor pajak. Sebaliknya alasan BPN mengeluarkan surat edaran tersebut adalah untuk mempercepat proses penerbitan akta tanah dan bangunan dalam rangka meningkatkan kualitas pelayanan kepada masyarakat.BPN berpendapat bahwa dengan adanya verfikasi SPPD BPHTB sering sekali terjadi keterlambatan BPN dalam memproses akta tanah atau bangunan karena salah satu persyaratan dalam pengurusan akta tanah atau bangunan adalah harus menunjukan bukti tanda verifikasi SPPD BPHTB oleh DPPKAD

\section{E. PENUTUP}

\section{Kesimpulan}

Berdasarkan hasil kajian, ditemukan beberapa kendala yang dihadapi oleh Pemerintah Kota Gunungsitoli dalam pelaksanaan pengalihan Bea Perolehan Hak atas Tanah dan Bangunan (BPHTB) dari pajak pusat menjadi pajak daerah, sebagai berikut:

a. Kondisi Gedung Kantor DPPKAD yang belum layak untuk ditempati dan difungsikan sebagai tempat bekerja dan melakukan pelayanan kepada masyarakat khususnya wajib pajak BPHTB dan ketersediaan ruangan yang sangat terbatassehingga menghambat kelancaran pelaksanaan tugas dan menimbulkan ketidaknyamanan baik para pegawaii dalam bekerja maupun masyarakat yang membutuhkan pelayanan.

b. DPPKAD Kota Gunungsitoli tidak memiliki strategi yang tepat dalam menggali dan meningkatkan pendapatan dari hasil pemungutan BPHTB.

c. SOTK DPPKAD Kota Gunungsitoli belum disesuaikan dengan Permendagri Nomor 56 Tahun 2010 sehingga penambahan beberapa fungsi pengelolaan BPHTB belum dilakukan.

d. DPPKAD Kota Gunungsitoli tidak memiliki analisis beban kerja dan analisis jabatan sehingga tidak diketahui jumlah kebutuhan pegawai dan jabatan pada unit kerja tersebut.

e. Kurangnya pemahaman masyarakat tentang BPHTB dan prosedur pemungutan BPHTB melalui self assessment system.

f. Kurangnya pelaksanaan pengembangan pendidikan bagi para pegawai DPPKAD dan keterbatasan anggaran untuk pelaksanaan pelatihan atau pun untuk pembiayaan keikutsertaan pegawai DPPKAD dalam mengikuti pelatihan yang diadakan oleh pemerintah pusat maupun pemerintah provinsi.

g. Penyusunan dan perumusan peraturan-peraturan daerah terkait dengan pengelolaan BPHTB di Kota Gunungsitoli tidak melalui sebuah kajian akademis dari para pakar yang ahli dalam bidang perpajakan.

h. Ketidaksepahaman DPPKAD Kota Gunungsitoli dan Badan Pertanahan Nasional dalam pelaksanaan verifikasi SPPD BPHTB atau pengecekan tanda bukti pembayaran BPHTB oleh wajib pajak.

\section{Saran}

Beberapa saran diberikan untuk mengatasi kendala yang dihadapi oleh pemerintah Kota Gunungsitoli dalam pelaksanaan pengalihan BPHTB dari pajak pusat menjadi pajak daerah, antar lain adalah: 
a. Penambahan anggaran untuk percepatan penyelesaian pembangunan gedung kantor DPPKAD Kota Gunungsitoli dan penambahan ruangan kerja dan pelayanan sekaligus pembiayaan untuk pelaksanaan dan keikutsertaan pegawai DPPKAD dalam pelatihan-pelatihan yang dilaksanakan oleh pemerintah pusat atau pemerintah provinsi.

b. Perlu adanya komunikasi politik yang lebih intensif dan efektif antara Pemkot Gunungsitoli dengan DPRD agar penetapan perda yang mengatur tentang SOTK Dinas PPKAD sesuai dengan Permendagri Nomor 56 Tahun 2010 segera ditetapkan.

c. Melaksanakan kerjasama dengan lembaga atau kementerian pada pemerintah pusat maupun pemerintah provinsi seperti Kementerian Keuangan atau lembaga-lembaga lainnya dalam menyusun dan merumuskan strategi peningkatan penerimaan BPHTB, analisis beban kerja dan analisis jabatan, serta penyusunan kajian akademis tentang peraturan-peraturan daerah terkait BPHTB.

d. Pelaksanaan sosialisasi secara rutin dan berkesinambungan kepada masyarakat tentang BPHTB dan prosedur pemungutannya.

e. Membentuk forum diskusi antara DPPKAD Kota Gunungsitoli dengan Kantor Pertanahan Kabupaten Nias untuk membahas dan menetapkan system dan prosedur yang tepat dalam melaksankan verifikasi SPPD BPHTB agar tidak menghambat pelayanan pembuatan akta tanah dan bangunan sekaligus dala rangka meningkatkan pengawasan terhadap pembayaran BPHTB oleh wajib pajak.

\section{DAFTAR PUSTAKA}

Abuyamin, Oyok. (2015). Pilar-Pilar Perpajakan. Bandung: CV Adoya Mitra Sejahtera.

Bardach, E. (2012).A Practical Guide for Policy Analysis: The Eightfold Path to More Effective Policy Problem Solving. London, UK. SAGE Publication Ltd.

Buulolo, Yafet. (2015). Evaluasi Pengalihan Bea Perolehan Hak atas Tanah dan Bangunan (BPHTB) di Pemerintah Kota Gunungsitoli. Jurnal Ilmu Administrasi STIA-LAN Bandung, Vol XII, No. 3.

Considine, M. (2005). Making Public Policy: Institutions, Actors, Strategies. Cambridge UK, Polity Press.

Dwiputrianti, S. (2012). Kebijakan Penetapan Tarif Barang Publik dan Swasta: Konsep, Teori dan Aplikasi. Bandung: STIA LAN Bandung Press.

Moenir, A.S. (2000). Manajemen Pelayanan Umum Di Indonesia. Jakarta: Bumi Aksara.

Murwani, S. (2002). Evaluasi Terhadap Struktur Organisasi dan Tata Kerja Perangkat Daerah Kabupaten Grobogan. Tesis. Semarang: Universitas Dipenogoro Semarang.

Peraturan Bersama Menteri Keuangan dan Menteri Dalam Negeri Nomor 186/PMK-07/2010Nomor 53 Tahun 2010 tentang Tahapan Persiapan Pengalihan Bea Perolehan Hak atas Tanah dan Bangunan Sebagai Pajak Daerah.

Peraturan Daerah Kota Gunungsitoli Nomor 2 Tahun 2011 tentang Pajak Daerah

Peraturan Menteri Dalam Negeri Nomor 56 Tahun 2010 tentang Perubahan atas Peraturan Menteri Dalam Negeri Nomor 57 Tahun 2007 tentang Petunjuk Teknis Penataan Organisasi Perangkat Daerah. 
Peraturan Walikota Gunungsitoli Nomor 3 Tahun 2013 tentang Sistem dan Prosedur Pemungutan Bea Perolehan Hak atas Tanah dan Bangunan Kota Gunungsitoli.

Silalahi, Ulber. (2012), Metode Penelitian Sosial. Bandung: Refika Aditama.

Surat Edaran Kepala BPN Nomor 5/SE/IV/2013 tentang Pendaftaran Hak atas Tanah atau Pendaftaran Peralihan hak atas Tanah Terkait dengan Pelaksanaan Undang-Undang Nomor 28 Tahun 2009 tentang Pajak Daerah dan Retribusi Daerah.

Sutarto. (2012). Dasar-Dasar Organisasi. Yogyakarta: Gajah Mada University Press.

Tangkilisan, N.S. (2005). Manajemen Publik. Jakarta: PT Gramedia Widiasarana.

UU Nomor 28 Tahun 2009 tentang Pajak Daerah dan Retribusi Daerah. 
